Artur JANCZUK

Szkoła Główna Handlowa, Szkoła Doktorska, Warszawa, Polska

Adam KIERYLUK

\title{
Wybrane zabiegi perswazyjne w pierwszym i ostatnim orędziu Donalda Trumpa do Kongresu na tle tradycji wystapień State of the Union. Kontynuacja, ewolucja czy nowa jakość?
}

\author{
Selected Persuasive Tools in the First and the Last State of the Union Addresses \\ by Donald Trump, on the Background of the Tradition of Presidential Speeches \\ to Congress: Continuity, Evolution, or a New Quality?
}

\section{- Abstrakt •}

Zwycięstwo Donalda Trumpa w wyborach prezydenckich w 2016 r. zaskoczyło wielu komentatorów - wygrał bowiem polityk pod wieloma względami odznaczający się na tle konkurentów politycznych, kontrowersyjny i niewątpliwie nieortodoksyjny. Zmiana jakościowa - bez względu na to, czy oceniana jest pozytywnie, czy negatywnie - objęła m.in. takie aspekty jak instrumentarium marketingu politycznego oraz sposób mówienia przez kandydata o wartościach, różnicach partyjnych i podziałach społecznych. Ta nowa retoryka została przeniesiona na praktykę codziennego wypełniania obowiązków przez Prezydenta, znajdując wyraz m.in. w szeroko komentowanych, dorocznych orędziach do Kongresu, znanych najszerzej jako State of the Union Addresses. Chcąc dokonać przynajmniej częściowego opisu specyfiki perswazji Trumpa i prześledzić

\section{- Abstract •}

The 2016 Donald Trump's electoral victory was a surprise to many commentators - the winning candidate is an undoubtedly controversial, unorthodox figure, clearly standing apart among other politicians. The qualitative change - whether positive or negative - embraces such aspects as the employed instruments of political marketing and the narrative on values, political differences and social divisions. After the 2016 elections, the new rhetoric influenced the everyday execution of Presidential duties, including the widely-commented speeches to Congress, mostly known as "State of the Union Addresses". In order to provide at least a rudimentary description of D. Trump's persuasive tactics and their evolution, the authors characterize the background of such speeches and analyze two selected addresses - the first one (from 2017), and the last one 
jej ewolucję, autorzy prezentują ogólne tło tego rodzaju wystąpień oraz analizują dwa wybrane przemówienia - pierwsze, z roku 2017, oraz ostatnie, z roku 2020. Na podstawie tego badania stawiają wniosek, że Trump nie zerwał całkowicie $\mathrm{z}$ tradycją orędzi prezydenckich i nie odrzucił narzędzi już wcześniej używanych; nie przeniósł ich jednak również bezpośrednio na swoje wystąpienia, zamiast tego dokonując reinterpretacji w ramach własnego, unikalnego stylu.

Słowa kluczowe: State of the Union; orędzie; Donald Trump; Kongres; perswazja (from 2020). The analysis allows the authors to conclude that $\mathrm{D}$. Trump did not abandon all of the traditional qualities and persuasive tools of Presidential speeches in Congress. On the other hand, he also did not adopt all of them directly. Instead, he reinterpreted them, thus creating his own, unique style.

Keywords: State of the Union; presidential address; Donald Trump; Congress; persuasion

\section{Wprowadzenie}

Zwycięstwo Donalda Trumpa w wyborach prezydenckich w 2016 r. dla wielu środowisk stanowiło duże zaskoczenie - sylwetka tego kandydata znacznie odbiegała od stereotypowych wyobrażeń o amerykańskim prezydencie. Zaskoczenia nie demonstrowały zresztą wyłącznie środowiska liberalne - nawet wewnątrz Partii Republikańskiej Trump postrzegany był bowiem jako osobowość znacznie się wyróżniająca (przy czym różnice te interpretowane były zarówno w sposób pozytywny, jak i negatywny). Nietypowa relacja z republikańskim establishmentem, a także specyficzne podejście do kluczowych wartości i dotychczas obowiązującej retoryki partii konserwatywnej, stanowiące raczej reinterpretację niż bezpośrednią kontynuację, sprawiły, że tożsamość 45 . Prezydenta USA zaczęła być postrzegana w kontekście renesansu ruchów populistycznych i odejścia od tradycyjnej percepcji sceny politycznej przez pryzmat dychotomii Partii Demokratycznej i Partii Republikańskiej. Zresztą, nawet w bardziej zniuansowanej osi lewica - prawica, to nowe podejście stanowiło zjawisko o tyle wykraczające poza ortodoksyjny podział, że doczekało się powiązania z publicystycznym terminem „alt-prawica [alt-right]” - tak, jak gdyby określenie „prawica”, pomimo całościowego obejmowania szerokiego spektrum ruchów politycznych, w sposób niewystarczający oddawało specyfikę tego eklektycznego nurtu.

Donald Trump to polityk w pełnym znaczeniu tego słowa kontrowersyjny - do tego wręcz stopnia, że nawet określenie go mianem „skutecznego” musi wzbudzić zarówno aprobatę, jak i sprzeciw, zależnie od audytorium. Wątpliwości te będą jednak dotyczyły przede wszystkim postrzegania w dłuższej perspektywie (całej prezydentury lub wręcz całej działalności publicznej). Tymczasem nie ulega wątpliwości, że już samo zwycięstwo w wyborach prezydenckich w USA można nazwać znaczą- 
cym sukcesem marketingu politycznego. Casus Trumpa jest jednak interesujący analitycznie nie tylko z powodu objęcia przez niego urzędu, lecz także ze względu na wykorzystanie instrumentów wykraczających poza ściśle pojętą tradycję polityczną amerykańskiej prezydencji, znamiennych dla większej, transgranicznej grupy ruchów politycznych. $Z$ tego też względu zasadne wydaje się zbadanie przynajmniej wycinka środków perswazyjnych, które stanowiły (i stanowią nadal, choć w mniejszym zakresie) o popularności Trumpa. Wygłaszane raz w roku orędzie Prezydenta do Kongresu (znane szerzej pod nazwą State of the Union Address [lub Speech]) jest przez niektórych autorów uważane za najważniejsze publiczne wystąpienie Prezydenta w roku; toteż zdaje się stanowić właściwy punkt wstępu do analizy. Nie ulega jednak wątpliwości, że i sama retoryka Trumpa - podobnie jak każdego innego polityka - ewoluuje z czasem. Jeszcze większą zawartość informacyjną, i jeszcze większy potencjał eksplanacyjny, ma więc wzbogacenie badania o analizę porównawczą, obejmującą dwa najbardziej odległe przemówienia - spośród których pierwsze odbyło się w roku 2017 (mimo że formalnie nie stanowiło przypadku State of the Union Speech; zastrzeżenie to zostało szerzej omówione w dalszej części tekstu), a ostatnie w roku 2020.

\section{State of the Union Address - istota i funkcja}

W sekcji III art. 2 Konstytucja Stanów Zjednoczonych nakłada na Prezydenta USA obowiązek dostarczania „co pewien czas” Kongresowi sprawozdania na temat „stanu Unii”, tzn. państwa amerykańskiego, wraz z rekomendacjami dotyczącymi środków, które w ocenie Prezydenta powinny zostać podjęte (źródło 1, b.r.). Za dokonaną przez Franklina D. Roosevelta parafrazą tekstu Konstytucji (Shogan, 2015) sprawozdanie to jest obecnie znane jako State of the Union Address i zaliczane do tzw. komunikatów styczniowych [January messages], czyli serii referatów, co do zasady przedstawianych przez Prezydenta na początku roku kalendarzowego (w ich skład wchodzą także sprawozdania ekonomiczne i uzasadnienie ustawy budżetowej; Pious, 1987, s. 245-246). Spośród nich State of the Union jest sprawozdaniem najbardziej ogólnikowym i swobodnym, a jednocześnie najmniej technicznym (por. Redford i in., 1965, s. 298). Warto jednak zauważyć, że wszystkie prezydenckie January messages mają zasadniczą przewagę diagnostyczną, eksplanacyjną i prognostyczną nad sprawozdaniami przedstawianymi przez inne organy, ponieważ przygotowywane są przez organ naczelny, a więc instancję posiadającą najszerszy dostęp do informacji i najbardziej rozbudowany aparat służący ich anali- 
zie. Treść State of the Union Address stanowi bowiem pochodną specyficznego procesu przygotowawczego, który obejmuje:

1. Przygotowanie programów w ramach poszczególnych agencji.

2. Proces międzyagencyjny:

a) debatę w obrębie egzekutywy;

b) podjęcie decyzji, rozstrzygnięcie sporów.

3. Prezentację efektu końcowego (por. Pious, 1987, s. 246).

Organy administracji uczestniczące $\mathrm{w}$ tej procedurze jako jedyne mają więc możliwość przygotowania kompleksowego programu i dokonania pełnej deskrypcji. Z tego właśnie względu Kongres - do momentu wygłoszenia State of the Union - zazwyczaj zajmował się jedynie pracami mniejszej wagi, oczekując na zarys prezydenckiej agendy legislacyjnej (Sokolewicz, 1977, s. 364).

W związku z niezbyt precyzyjnym językiem, jakim została napisana amerykańska Konstytucja, podobnie jak w wielu innych przypadkach (Plano, Greenberg, 1962, s. 17; Beard, 1926, s. 100-101), szczegółowe normy dostarczania przez Prezydenta informacji w ramach State of the Union zostały uregulowane na zasadzie konwenansu. Zgodnie z ogólną regułą tego typu informacje powinny być upubliczniane co roku (dopuszcza się jednak pewne odstępstwa i różnorodne konfiguracje) w celu umożliwienia Kongresowi sprawowania formalnej kontroli parlamentarnej nad egzekutywą. Początkowo, zarówno z przyczyn praktycznych, jak i symbolicznych, State of the Union najczęściej przesyłano w formie pisemnego, wysoce technicznego raportu, stanowiącego suche wypełnienie dyrektywy konstytucyjnej (dla zobrazowania: pierwszy w historii, ogólnikowy tekst tego rodzaju autorstwa Jerzego Waszyngtona, liczył zaledwie ok. trzech stron maszynopisu; por. Washington, b.r.). W późniejszym okresie - wraz z rozwojem środków masowego przekazu oraz zwiększeniem znaczenia State of the Union - przyjęto praktykę nakazującą prezentowanie tych informacji w formie (szeroko transmitowanego i komentowanego) przemówienia do połączonych izb Kongresu podczas uroczystego posiedzenia (Kolakowski, Neale, 2002).

Należy również nadmienić, że termin State of the Union Address niejednokrotnie traktowano w sposób umowny. Zdarzało się bowiem, że w poczet przemówień tej kategorii zaliczano wystąpienia Prezydenta w Kongresie, które formalnie nie miały nic wspólnego z III sekcją art 2 Konstytucji, lecz wyróżniały się podobną formułą, oprawą i znaczeniem (funkcją). Zważywszy na niewielką precyzję samej dyrektywy, wymuszającej wypracowywanie konkretnych rozwiązań w drodze zwyczaju i sprawiającej, że techniczne szczegóły związane z tego rodzaju komunikatami (np. układ treści, dokładna zawartość, termin prezentacji) traktowane są stosunkowo swobodnie, a różnice dotyczą wyłącznie strony formalnej, kwestia ta zdaje się 
nie mieć większego, praktycznego znaczenia dla badań zjawiska. Z tego też względu, podobnie jak w znacznej części literatury przedmiotu, na potrzeby niniejszego opracowania przyjęto traktowanie wspomnianych przemówień w taki sam sposób jak ich właściwych, stricte „konstytucyjnych” odpowiedników.

O doniosłości State of the Union dla badań polityk rządu federalnego USA świadczy chociażby to, jak wielkie znaczenie polityczne i symboliczne ma cały szereg deklaracji, które padły właśnie w ramach realizacji przez Prezydenta dyrektywy art. 2 Konstytucji (była to np. prezentacja doktryny Monroego, „,czterech wolności” Franklina D. Roosevelta czy też narracja o „osi zła” George’a W. Busha; Peters, 2021). Ze względu na swój doniosły charakter orędzie takie stanowi doskonałą okazję do zaprezentowania kluczowych założeń doktrynalnych, stanowiących podstawę większości działań podejmowanych w kolejnych latach. Jak pokazują badania, wystąpienia Prezydenta USA mają moc nie tylko prezentacji propozycji rozwiązań problemów już znajdujących się w obiegu, lecz także efektywnego kierowania uwagi opinii publicznej, polityków i urzędników na zagadnienia, którym wcześniej nie przyznawano priorytetu (Cohen, 1995, s. 87, 93-96). W tym właśnie znaczeniu State of the Union Addresses mogą służyć jako narzędzie do kreowania całkowicie nowych pól w debacie publicznej, stanowiąc zapowiedź obszarów, które znajdą się w centrum prezydenckiej agendy.

Należy jednak pamiętać, że wraz ze wzrostem rangi wydarzenia i powiększaniem liczby słuchaczy (od samego Kongresu i jego ścisłego otoczenia w pierwszych latach istnienia Stanów Zjednoczonych do dziesiątek milionów Amerykanów obecnie, źródło 2,2017) przemówienie przestało pełnić funkcję roboczej wymiany informacji, a stało się - obok środka zwiększania skuteczności inicjatyw legislacyjnych - produktem marketingu politycznego, przeznaczonym przede wszystkim dla obywateli (wyborców) stanowiących ogromną większość jego faktycznych adresatów. Z tego też względu w tej samej (jeśli nie większej) mierze, co źródłem informacji o sensu stricto polityce prowadzonej przez Biały Dom, jest ono materiałem do badań narracji, jaką Prezydent i jego środowisko chcą prowadzić na temat otaczającej ich rzeczywistości. Obok deklaracji ideologicznych (programowych), wyznaczających ramy przyszłych działań, a także diagnozy współczesnej sytuacji i analizy jej przyczyn, jest to kwestia o dużym znaczeniu - nie ulega wątpliwości, że jednym z ważnych uwarunkowań, kształtujących podejmowane decyzje, jest percepcja stanu środowiska przez decydentów - nawet (lub, z innego punktu widzenia, zwłaszcza) wówczas, gdy jest ona z gatunku tych surrealistycznych (Pietraś, 2004, s. 15-17). Analiza zarówno samej treści, jak i języka przemówień polityków daje wgląd w kształt tej percepcji i umożliwia lepsze zrozumienie przesłanek stojących za podejmowanymi decyzjami. 


\section{State of the Union Addresses Donalda Trumpa}

Pomimo różnorodności komunikatów i stylów State of the Union Speeches, wymuszanych przez zmienność sytuacji, specjaliści z Congressional Research Service przytaczają szereg cech wspólnych, charakterystycznych dla tego rodzaju wystąpień:

1. Wezwania do współpracy między partiami politycznymi.

2. Odniesienia do sfery wartości.

3. Optymistyczna wymowa.

4. Skupienie na przeszłości i przyszłości (Shogan, 2015).

Orędzia Donalda Trumpa najdalej wykraczają poza ten schemat w przypadku pierwszego z przytoczonych punktów. W tekstach tych przemówień wezwania do tzw. bipartisanship, czyli kompromisu prowadzącego do wspólnego poparcia danego projektu, zdarzają się sporadycznie (wszystkie cytaty z orędzia do Kongresu z 2017 r. za: Trump, 2017; wszystkie cytaty z orędzia do Kongresu z 2020 r. za: Trump, 2020). Przypadkiem takiego rzadkiego wystąpienia w przemówieniu z roku 2020 było użycie właśnie terminu bipartisanship w kontekście ustawy przedłużającej urlopy macierzyńskie i ojcowskie. W tym samym State of the Union znalazły się jednak również sformułowania dokładnie przeciwne duchowi kompromisu, tzn. zawierające otwarty sprzeciw wobec działań parlamentarzystów niechętnych ówczesnej prezydencji. Wyjątkowo ostrym zabiegiem retorycznym było oskarżenie „ponad 130 prawodawców [legislators] obecnych w [...] Izbie” o „wsparcie projektu, który doprowadziłby naród do bankructwa poprzez dostarczanie za darmo opłaconej przez podatników opieki medycznej dla nielegalnych imigrantów”. Trump w podobnym tonie odwołał się również do polityków lokalnych, spoza parlamentu, wskazując na zjawisko tzw. sanctuary cities (miejscowości, których administracja lokalna współpracuje $\mathrm{z}$ federalnymi organami imigracyjnymi jedynie w ograniczonym zakresie - stwarzając tym samym bardziej stabilne warunki dla osób przebywających na terytorium USA nielegalnie; taktyka ta jest o tyle efektywna, że zadania związane z egzekwowaniem prawa realizowane są przede wszystkim przez organy poziomu stanowego i niższego, a federalne organy imigracyjne posiadają ograniczoną kompetencję rzeczową nawet w obrębie polityki imigracyjnej; Farris, Holman, 2017, s. 142-145; Gonzalez i in., 2019, s. 3, 8-9). Urzędników administracji tych miast Trump w 2020 r. określił mianem „radykalnych”, jednocześnie wzbogacając typowy już termin illegal aliens o wzmacniające przekaz przymiotniki „kryminalny” [criminal], a nawet emocjonalne „niebezpieczny [i] kryminalny" [dangerous criminal $]$. 
Przy okazji tego ostatniego przypadku należy wspomnieć również o zabiegu polegającym na przywoływaniu przykładów dotyczących poszczególnych osób, najwcześniej zapraszanych na widownię podczas sesji obejmującej przedstawienie State of the Union. Jest to technika często stosowana przez Donalda Trumpa. W przypadku krytyki sanctuary cities polegała ona na przywołaniu przykładów przestępstw popełnionych przez nielegalnych imigrantów, przebywających na wolności dzięki rozwiązaniom przyjętym w tych miejscowościach, na obywatelach amerykańskich (rodzinę jednego z pokrzywdzonych zaproszono na galerię sali). Analogiczny zabieg po raz pierwszy zastosowano w roku 2017. Z kolei w 2020 r. tego rodzaju „przykłady z życia” obejmowały również ofiary terroryzmu islamskiego na Bliskim Wschodzie, sygnalizując obszary wymagające podjęcia działań; ale także ukazywały przypadki sukcesów administracji - chociażby w postaci beneficjentów programów federalnych (tutaj „Stref Możliwości” [Opportunity Zones] stworzonych przez ustawę o cięciach podatkowych i miejscach pracy [Tax Cuts and Jobs Act]). Wyjątkowymi, ze względu na oddziaływanie wizerunkowe, przypadkami zastosowania podobnej techniki są jednak wypowiedzi Trumpa na temat czwartoklasistki z Filadelfii oraz matki dwojga dzieci i jednocześnie żony żołnierza z Fort Bragg. W pierwszym przypadku Trump podczas przemówienia poinformował dziewczynkę i jej rodzinę o udostępnieniu jej stypendium, pozwalającego na opłacenie bardziej prestiżowej edukacji (co ciekawe, w wypowiedzi na ten temat znalazło się również stwierdzenie: „żaden rodzic nie powinien być zmuszany do wysyłania swojego dziecka do upadającej szkoły rządowej" - w imię wsparcia tezy o wyższości „państwa minimum” Trump przyznał zatem, zresztą nie po raz pierwszy, że jakość realizacji usług publicznych przez samą egzekutywę jest niezadowalająca). W drugim przypadku Trump poinformował kobietę o powrocie jej męża z misji w Afganistanie. Oba te zabiegi zasługują na uwagę, gdyż mają na celu wytworzenie skojarzenia między osobą mówcy a pozytywnym, silnie nacechowanym emocjonalnie wydarzeniem.

Nieznaczne nasycenie elementami związanymi z bipartisanship nie oznacza jednak całkowitego opuszczenia tematu jedności. W orędziu z 2017 r. znajdują się bowiem przykłady odniesień do społecznego zjednoczenia; nie dotyczą one jednak podziałów partyjnych. Zamiast tego zastosowano zabiegi związane z różnicami rasowymi, światopoglądowymi i związanymi z miejscem zamieszkania („rodziny wszystkich kolorów i światopoglądów [...] z miast małych i dużych" [families of all colors and creeds [...] from cities small and large]). Słowa te były istotne $\mathrm{z}$ dwóch powodów: po pierwsze, stanowiły odpowiedź na obawy i oskarżenia kierowane przez opozycję pod adresem Donalda Trumpa i jego otoczenia. Zastrzeżenia te dotyczyły bardzo często stanowiska tej grupy w kwestiach rasowych oraz pogłębiania polary- 
zacji politycznej. Z kolei w sferze gospodarczej odwoływały się do konserwatywnych postulatów gospodarczych, opłacalnych (zdaniem krytyków) przede wszystkim dla grup najlepiej uposażonych; innymi słowy, wzmacniających rozwarstwienie ekonomiczne. Tym większe znaczenie ma więc cytowane sformułowanie, umieszczone w kontekście początków szerokiego ruchu sprzeciwu wobec polityki poprzednich administracji, który wedle tej narracji miał doprowadzić do zwycięstwa Trumpa. Umieszczając w jego zalążku „rodziny wszystkich kolorów i światopoglądów [...]”, autorzy tekstu odsuwają od siebie zarzut dyskryminacji rasowej, niechęci do współpracy ponad podziałami oraz stosowania polityki gospodarczej nasilającej stratyfikację poziomą. Inne wzmianki o współpracy pomimo różnic również pomijały aspekt typowo polityczny, przybierając formę aluzji lub stwierdzeń nieprecyzujących dokładnej natury podziałów (np. „Czas pospolitych kłótni jest za nami” [The time for trivial fights is behind us]). Po drugie, odejście od interpretacji polityki przez pryzmat afiliacji partyjnych i, zamiast tego, skupienie na innych, bardziej namacalnych podziałach mogą świadczyć o postrzeganiu „postpartyjnym” - zwłaszcza że nawet w Partii Republikańskiej Trumpa postrzegano jako polityka raczej nieortodoksyjnego, w wielu kwestiach wyłamującego się z linii tego stronnictwa. W State of the Union $\mathrm{z}$ ostatniego roku prezydentury próby zasypywania podziałów były już rzadsze, ale nadal występowały. Ich przykładem może być przywołanie postaci Martina Luthera Kinga i Abrahama Lincolna (w kontekście „odrzucania ograniczeń dla przyszłości naszych dzieci” w sposób nawiązujący do działalności obu tych postaci). Zaskakujące, w świetle ogólnej retoryki konserwatywnej administracji, jest z kolei dwukrotne użycie wyrazu „inkluzywny” [inclusive] („budujemy najlepiej prosperujące i najbardziej inkluzywne społeczeństwo" [we are building the world's most prosperous and inclusive society] oraz „następny krok w budowie inkluzywnego społeczeństwa to..." [the next step in building an inclusive society is...]). Kontekst pierwszego wystąpienia tego terminu stanowiło wprowadzenie do kilku akapitów poświęconych redukcji bezrobocia, w których dużo uwagi poświęcono istnieniu tego problemu wśród kobiet i mniejszości (Afroamerykanów, Latynosów i Azjatów). Podobnie jak w 2017 r., był to akcent stanowiący odpowiedź na typową krytykę i wpisujący się w stosunkowo standardową narrację konserwatywną, w kontekście nierówności społecznych akcentującą społeczną dyfuzję - tutaj w postaci udziału grup poszkodowanych nierównościami społecznymi w ogólnym wzroście generowanym politykami makroekonomicznymi niededykowanymi konkretnym mniejszościom (tutaj: polityką deregulacji gospodarczej). Taktyka ta wiąże się również z tradycją konserwatywnej polityki realnej, odrzucającej zagadnienia sprawiedliwości społecznej i zrównoważonego rozwoju, a w zamian oferującej koncentrację na wzroście nominalnym. 
Jak wskazują niektórzy badacze, w kwestiach doktrynalnych szczególnie istotne jest pierwsze wystapienie State of the Union, tzn. to ogłoszone podczas pierwszego roku prezydentury. Wynika to z faktu, że nowo wybrany Prezydent co do zasady stara się wyraziście i atrakcyjnie zaprezentować sposób funkcjonowania nowej administracji oraz nakreślić plany legislacyjne na czas czteroletniej kadencji (Shogan, 2015). Stąd też State of the Union z 2017 r. w największym zakresie obejmowało dwa elementy: krytykę poprzedniej administracji oraz deklaracje programowe. Obie te sfery przeplatają się przez większość przemówienia. Oznacza to, że rzeczywiście tekst ten zgodny jest z przytaczanymi wcześniej tendencjami ogólnymi: nasycony jest odniesieniami do przeszłości (krytyka) oraz do przyszłości i ma optymistyczną wymowę w tym drugim zakresie. Dotychczasowe problemy omawiane są w zasadzie wyłącznie jako wywołane, częściowo lub w całości, działaniami poprzednich administracji. Zmiana ekipy rządzącej w tej narracji stanowi zatem punkt zwrotny. Znamienne jest tutaj zdanie: „Nie pozwolę, aby błędy minionych dekad definiowały naszą przyszłość”.

Przemówienie z 2017 r. znacząco różni się od tego z roku 2020 również pod względem odniesień do sfery wartości. W pierwszym orędziu poświęcono im znacząco więcej uwagi, wymieniając expressis verbis „prawdę, wolność i sprawiedliwość już w drugim akapicie. W dalszej części tekstu pojawiały się także odniesienia do wartości chrześcijańskich. W 2020 r. narracja skupiła się raczej na elementach pragmatycznych, przede wszystkim o charakterze ekonomicznym; w zasadzie jedyną otwarcie wymienioną wartością była wolność („Socjalizm niszczy narody. Ale zawsze pamiętajcie: wolność spaja duszę" [Socialism destroys nations. But always remember: freedom unifies the soul] - w kontekście sytuacji w Wenezueli). Nawet gdy sfera wartości przywoływana była wprost, czyniono to w sposób raczej mniej abstrakcyjny, a bardziej praktyczny - jak w przypadku wolności religijnej, do której odniósł się Donald Trump, posługując się przykładem gwarancji „prawa do modlitwy" w szkołach publicznych.

Sfery wartości dotyka jednak również bardzo charakterystyczny zabieg obecny w obu orędziach - polega on na płynnym przejściu w ostatnich akapitach obu State of the Union Adresses do zarysowania spójni między inspiracją przeszłością i wizją przyszłości USA. We wskazanych przypadkach wartości ważne dla mówcy nie są nazywane wprost; prezentuje się je raczej przez peryfrazę. Zarówno w 2017, jak i 2020 r. skupiono się w tym zakresie na obszarach postępu naukowo-technologicznego, rozwoju kulturalnego, wzrostu gospodarczego, innowacji, wytrwałości i ekspansji; fragmenty aksjologiczne zawierały jednak również odniesienia do Boga i zapowiadały rozkwit Stanów Zjednoczonych dzięki unikatowym wartościom tego 
narodu (w duchu poglądu określanego jako exceptionalism, silnie obecnego w tradycji konserwatywnej amerykańskiej myśli politycznej i społecznej). Przeszłość w tym rozumieniu predestynuje USA do świetlanej przyszłości, gdyż - poprzez historyczne sukcesy - dowodzi istnienia cech determinujących powodzenie narodu amerykańskiego.

Wraz z upływem czasu, a więc zbliżającą się datą wyborów, w przemówieniach zwykle dodatkowo narasta optymizm wobec dotychczasowych osiągnięć, czyli tym samym wobec tytułowego „stanu unii” - np. jako szczególnie optymistyczne oceniane przez dziennikarzy i publicystów było ostatnie tego rodzaju wystąpienie Baracka Obamy (Shogan, 2015; por. Collinson, 2016) - nawet pomimo faktu, że zgodnie z prawem nie mógł on kandydować w nadchodzących wyborach (choć, oczywiście, brała w nich udział kandydatka Partii Demokratycznej). W przypadku Donalda Trumpa zmiana retoryki dotyczyła głównie zamiany proporcji - w przeciwieństwie do wystąpienia z 2017 r. w roku 2020 dominowały odniesienia do przeszłości obejmującej ostatnie lata - a więc do działań bieżącej administracji, przedstawianych oczywiście w korzystnym świetle. Ograniczeniu uległa natomiast objętość nowych propozycji programowych, jak również krytyki poprzedniej administracji. Nawet pomimo częściowego zrównoważenia tego ubytku większym emocjonalnym nacechowaniem tej krytyki (dzięki przedstawieniu, opisanych wcześniej, realnych i namacalnych przykładów osób zasiadających na widowni) można stwierdzić, że podczas ostatniego State of the Union uwagę skupiono raczej na walorach rządzącego Prezydenta aniżeli na niedostatkach przeciwników.

\section{Zakończenie}

Każde State of the Union Address niewątpliwie jest istotnym źródłem wiedzy o polityce wewnętrznej i zagranicznej USA - nie tylko przyszłej (zarysowywanej w programie politycznym Prezydenta i jego obozu oraz w planach egzekutywy), lecz także przeszłej - zawiera bowiem subiektywny, spreparowany na potrzeby bieżące wynik ewaluacji tych polityk, dokonanej przez organ dysponujący najszerszymi informacjami, nieraz niedostępnymi dla opinii publicznej, i najbardziej rozbudowanym aparatem ich przetwarzania. Co więcej, ze względu na tradycyjnie duże znaczenie orędzi do Kongresu, z jednej strony legislatywa, stronnictwa polityczne i opinia publiczna oczekują, że komunikat będzie obfitował w treści o dużej wadze i szeroko go komentują, a z drugiej - właśnie z tego powodu - prezydenci amerykańscy celowo wybierają to wydarzenie na moment prezentacji podstawowych założeń swojej polityki. 
Orędzia Donalda Trumpa stanowią specyficzne połączenie tradycyjnych elementów State of the Union Addresses z taktykami o charakterze stosunkowo nowatorskim. Najbardziej reprezentatywnym przykładem tego faktu jest narracja o podziałach społecznych i ich niwelowaniu. Wezwania do ograniczenia polaryzacji stanowią kanon środków wykorzystywanych w przemówieniach prezydenckich, a ich najbardziej konserwatywne wydanie - tzn. apele o praktykowanie bipartisanship w parlamencie - znalazły się w tekstach orędzi. U Trumpa ujęcie polaryzacji przez pryzmat partii politycznych wyraźnie ustępuje jednak miejsca narracji przenoszącej środek ciężkości na podziały rasowe, terytorialne czy - w pewnym stopniu - klasowe; nawet różnice światopoglądowe ujęte zostały z pominięciem optyki typowo partyjnej.

Przedstawiona problematyka łączy się z koncepcją interesu ekonomicznego jako spajającego społeczeństwo, czego najbardziej charakterystycznym przykładem są narracje z 2017 r. o pełnych wielowymiarowej różnorodności korzeniach ruchu sprzeciwu wobec poprzedniej administracji oraz z 2020 r. o zjednoczeniu (obejmującym też mniejszości rasowe, wymienione expressis verbis) wokół wzrostu gospodarczego (i dyfuzji bogactwa) jako wspólnego celu. Narracja o zasypywaniu podziałów społecznych poprzez partycypację w „odnowie gospodarczej” mogła zresztą powstać dzięki temu, że sfera przywoływanych wprost wartości ograniczona została tylko do ogólnoludzkiego kanonu - „prawdy, wolności i sprawiedliwości” które, jeżeli (jak to uczynił Donald Trump) pozostawione zostaną bez interpretacyjnego komentarza, można potraktować jako praktycznie całkowicie uniwersalne. Cele gospodarcze są jednocześnie wobec powyższych pojęć o tyle komplementarne, że jednym z najważniejszych narzędzi prób ich realizacji była deregulacja.

State of the Union Addresses z 2017 i 2020 r. zawierają co prawda także akcenty chrześcijańskie, lecz w realiach północnoamerykańskich można je również potraktować jako stosunkowo uniwersalne. Ich obecność w obu orędziach jest jednak o tyle istotna, że wiąże się z dyskursami na temat przeszłości i przyszłości. W pierwszym przypadku uwagi dotyczące Boga padają w kontekście XVIII- i XIX-wiecznej historii państwa $\mathrm{i}$, wraz z opisem cech interpretowanych jako stanowiące o intensywnym rozwoju Stanów Zjednoczonych w tym okresie, portretowane są jako źródło siły i inspiracji. Drugim sposobem mówienia o przeszłości jest skupienie na ostatnich kilku latach i krytyka poprzednich ekip rządzących, przybierająca w zasadzie postać manichejską - poprzednie kadencje przedstawiane są wyłącznie jako źródło problemów i czas porażek oraz kontrastują z dynamicznymi reformami, które nastąpiły po zmianie Prezydenta (nawet jeżeli zmiana ta nastąpiła bardzo niedawno). Z kolei narracja na temat przyszłości jest całkowicie zgodna z tradycją 
orędzi prezydenckich, ponieważ jest niezmiennie optymistyczna. Na początku kadencji źródłem optymizmu są postanowienia o charakterze programowym; z kolei w jej ostatnim roku ich miejsce zajmuje ekstrapolacja wybranych, bieżących, pozytywnych trendów w przyszłość.

Można więc postawić tezę, że perswazyjny potencjał State of the Union Addresses Donalda Trumpa płynie przede wszystkim z reinterpretacji tradycyjnych cech tego typu przemówień. Prezydent ten nie zerwał z większością kierunków wcześniej praktykowanych. Żadnej z cech widocznych w poprzednich orędziach nie pozostawił jednak również bez korekty. Biorąc pod uwagę, że reinterpretacja ta polegała m.in. na zamianie tradycyjnego, partyjnego postrzegania sceny politycznej i społeczeństwa na typowe dla postparty politics oraz na przedstawianiu indywidualnych przykładów, co prawda anegdotycznych, ale nacechowanych emocjonalnie, można stwierdzić, że przyjęte sposoby działania czerpały z ogólnej narracji, prowadzonej przez administrację i otoczenie Trumpa. Pozwoliły więc na wykorzystanie utartych już sposobów konstruowania orędzi bez odrzucenia indywidualnych cech stanowiących o politycznej tożsamości konkretnego Prezydenta. $Z$ tychże powodów analiza treści State of the Union Addresses z 2017 i 2020 r. dostarcza wiadomości na temat źródeł oddziaływania perswazyjnego - uważanego często za zaskakujące - komunikatów konserwatywnej administracji z lat 2016-2020.

Same State of the Union pozostają znaczącym zjawiskiem jako przedmiot badań; zarówno stanowiący sam w sobie obiekt badań, jak i zawierający, uchwycony w pewną narrację polityczną, wynik analiz przeprowadzonych przez aparat administracyjny, wzbogaconych o stanowisko pozytywne, oparte na doktrynie prezentowanej przez samego Prezydenta i jego otoczenie. Dlatego też zasadne wydaje się, aby również w przyszłości śledzić trendy widoczne w narracjach pomiędzy kolejnymi orędziami pochodzącymi od tych samych administracji oraz State of the Union Speeches wygłaszanymi przez zmieniających się prezydentów. 


\section{Bibliografia:}

Beard, C.A. (1926). American Government and Politics. New York: The Macmillan Company. Cohen, J.E. (1995). Presidential Rhetoric and the Public Agenda. American Journal of Political Science, 25(1), 87-107. DOI: 10.2307/2111759.

Collinson, S. (2016). State of the Union: Barack Obama Sells Optimism to Nervous Nation. Pobrane z: http://edition.cnn.com/2016/01/12/politics/state-of-the-union-2016-highlights/index.html.

Constitution of the United States. Pobrane z: https://www.senate.gov/civics/constitution_ item/constitution.htm.

Farris, E.M., Holman, M.R. (2017). All Politics Is Local? County Sheriffs and Localized Policies of Immigration Enforcement. Political Research Quarterly, 70(1), 142-154. DOI: $10.1177 / 1065912916680035$.

Gonzalez, B., Collingwood, L., El-Khatlib, S.O. (2019). The Politics of Refuge: Sanctuary Cities, Crime, and Undocumented Immigration. Urban Affairs Review, 55(1), 3-40. DOI: $10.1177 / 1078087417704974$.

Kolakowski, M., Neale, T.H. (2002). The President's State of the Union Message: Frequently Asked Question. Pobrane z: https://web.archive.org/web/20060201152813/https:// www.senate.gov/artandhistory/history/resources/pdf/stateoftheunion.pdf.

Nearly 48 Million Americans Watch Pres. Donald Trump's First Address to Congress. Pobrane z: http:/www.nielsen.com/us/en/insights/news/2017/nearly-48-million-americanswatch-president-donald-trumps-first-address-to-congress.html.

Peters, G. (2021). Annual Messages to Congress on the State of the Union (Washington 1790the present). Pobrane z: http://www.presidency.ucsb.edu/sou.php.

Pietraś, Z.J. (2004). Teoria adaptacji politycznej państwa. W: A. Ziętek, K. Stachurska (red.). Adaptacja wartości europejskich w państwach islamu. Lublin: Wydawnictwo Uniwersytetu Marii Curie-Skłodowskiej.

Pious, R.M. (1987). Essentials of American Politics and Government. New York: McGraw Hill Book Company.

Plano, J.C., Greenberg, M. (1962). The American Political Dictionary. New York: Holt, Rinehart and Winston.

Redford, E.S. (i in.). (1965). Politics and Government in the United States. San Diego: Harcourt, Brace \& World.

Shogan, C.J. (2015). The President's State of the Union Address: Tradition, Function, and Policy Implications. Pobrane z: https://fas.org/sgp/crs/misc/R40132.pdf.

Sokolewicz, W. (red.). (1977). Instytucje polityczno-prawne Stanów Zjednoczonych Ameryki. Wrocław: Zakład Narodowy im. Ossolińskich-Wydawnictwo PAN.

Trump, D.J. (2017). Address Before a Joint Session of the Congress. Pobrane z: https://www. presidency.ucsb.edu/documents/address-before-joint-session-the-congress-2.

Trump, D.J. (2020). Address Before a Joint Session of the Congress on the State of the Union. Pobrane z: https://www.presidency.ucsb.edu/documents/address-before-joint-sessionthe-congress-the-state-the-union-27.

Washington, G. (b.r.). First Annual Address to Congress. Pobrane z: https://www.presidency.ucsb.edu/documents/first-annual-address-congress- 0 . 